\title{
Nickel slag waste utilization for road pavement material as strategy to reduce environmental pollution
}

\author{
Iwan Susanto*, Rulli Ranastra Irawan, Dani Hamdani \\ Institute of Road Engineering, Directorate General of Highway, Ministry of Public Works and \\ Housing, Republic of Indonesia
}

\begin{abstract}
The rapid growth of industry could result negative impact on the increasing volume of waste that has the potential to be serious problem for environment. Nickel slag is categorized as Hazardous and Toxic Substances which produced from nickel ore smelting and has large amount of deposits. On the other hand, suitable natural materials for road pavement are less available. Utilization of nickel slag for road pavement with massive, safe, and fulfil the specifications are one of the best solutions to offer. The purpose of this research is to obtain optimum composition to utilize nickel slag for pavement base, by laboratory testing consisting of physical test, chemical test, TCLP, and mechanical strength test. The result of chemical test showed that majority of compound contained are constituent element of cement as $\mathrm{SiO}_{2}, \mathrm{CaO}, \mathrm{Al}_{2} \mathrm{O}_{3}, \mathrm{Fe}_{2} \mathrm{O}_{3}$. TCLP test showed that toxic substances contained are lower than TCLP-B. The process of sudden cooling of molten slag in the granulation pond lowering the abrasion value of nickel slag. When the process changed without sudden cooling, the result of abrasion test is $39.5 \%$, angularity $100 / 100$, cubical shape, and the granular size can be adjusted as needed. CBR test result also increased up to $115 \%$, which fulfil for pavement base layer.
\end{abstract}

\section{Introduction}

The industrial sector is national priority for improve the economics of Indonesia. In addition of giving a positive impact on improving the economy, the rapid growth of the industrial sector can give a negative impact, namely increasing amount of waste. Industrial waste with large amount of deposits, are causing serious environmental problem in term of disposal area. These issues received serious attention from national and international environmental agencies. The government is constantly developed environmentally clean industries and encourage the proper use and improvement of the efficiency of industrial waste towards the application of sustainable material technology [1]. On the other hand, due to the sizable use of various materials that are available naturally for road construction and other infrastructure, these materials are gradually depleting. The cost of procurement and processing of such materials are increasing day by day [2]. It is in this connection, road

* Corresponding author: iwan.susanto@pusjatan.pu.go.id 
researches have been trying to find out possible ways to use some of the waste material as alternative materials for road construction [3]. Technical feasibility, environmental consequences, and economic benefits are the main thing that was taken into utilization industrial waste as road pavement materials [4]. That why, road research is needed to be able to utilize waste as road material, so that in addition to reducing pollution, it can also reduce dependence on standard materials for road.

The needs of nickel in Indonesia more ever in the world are increasing. Nickel is a mineral with very high economic value. Nickel is made by melting nickel ore from minerals. Nickel ore smelting process produces waste in the form of nickel slag which has very large deposits. The waste must be handled or utilized properly because it has the potential to cause environmental problems and social phenomena [5].

The main process of obtaining nickel slag through the smelting of nickel ore are: liquid slag with a temperature range of $\pm 1550^{\circ} \mathrm{C}$ is directly removed through the runner slag to the slag granulation pond which is equipped with a water jet, then the liquid slag flows underwent sudden cooling with the help of a water jet (high pressure spray) to break down the size of the slag to form granules.

The nickel slag waste deposit reaches 1 million tons per year, and the estimated total deposit of 2019-2024 reaches 14,173,000 tons [6]. The large deposits are potential to be used as road pavement for substituting natural material. The Indonesian government assigns nickel slag as hazardous and toxic waste category 2 from specific sources [7]. This cause extra efforts to utilize nickel slag for pavement material not only in technical issues but also in environmental issues. In addition, permits from the Ministry of Environment and Forestry are also important besides technical aspects fulfillment. In accordance with PP 101 of 2014, prior to utilization, materials which categorized as hazardous and toxic waste, must be tested to determine the content of hazardous substances in the waste, by Toxicity Characteristic Leaching Procedure (TCLP) test. Toxic characteristic test through this procedure are to determine the concentration of pollutant in nickel slag, whether it smaller or equal to the standard reference. The TCLP test results will also determine the category of waste, namely category 1 and or category 2 . Category 1 has a concentration of pollutants greater than the concentration of pollutants, listed in the TCLP-A column, while category 2 has a smaller or equal concentration of pollutants listed on concentration of pollutants in the TCLP-A column and has a concentration of pollutants greater than the concentration of pollutants listed in the TCLP-B column.

The potential use of nickel slag waste as a road pavement material will be greatly influenced by physical and chemical properties, so chemical testing in laboratory is necessary. The physical form of nickel slag that resembles natural rock, causing the potential as a road material for surface layers and foundation layers is very possible. Pavement structures generally consist of sub grade, embankment, sub base, base, and surface [8]. The structure of road pavement layer is accordance with Figure 1.

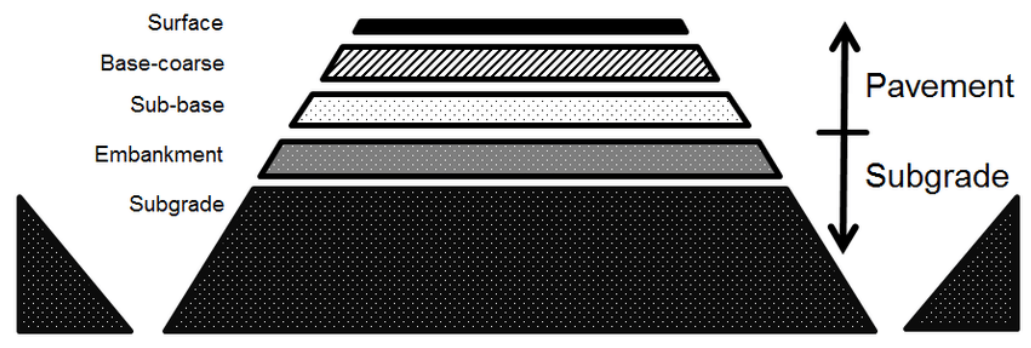

Fig 1. The Structure of Road Pavement Layer 
Layers in the pavement construction have their respective functions, namely:

- Surface layers, its function is to secure the pavement from the influence of water, reduce stress, and withstand the highest loads due to traffic loads so they must have relatively highest strength compared to other layer.

- Base and sub base layer, its functions is to support the surface layer and reduce stress and strain, and spread the load from above. If the foundation layer is damaged then the structure above its is affected, so the function of the base is very important in maintaining the load on it.

- Embankment layer, its function is to increase bearing capacity of sub grade or soil and to attain sub grade elevation in drawing plan

- Subgrade layer, its function is to supports the load distributed through the base layer above it

Utilizations of nickel slag in some areas are only for paving block and wall brick making, the utilization rate of nickel slag is very low at only $1 \%$ of the volume of nickel slag produced. The efforts to utilize nickel slag massively are in line with the 3 strategic plans of Ministry of Public Works in the field of road pavement, namely the use of local materials, recycling of road materials, as well as the utilization of waste for road pavement materials. One of the potential utilization to massively absorb nickel slag waste is as a base road pavement material. So the purpose of this research is how to utilize the nickel slag waste for base road pavement material in a massive, safe, and environmentally friendly manner, as well as fulfils the technical specifications for road materials.

\section{Methods}

Research on the utilization of nickel slag as road pavement material was carried out by experimental methods through laboratory testing. The tests included material quality tests, chemical properties tests, TCLP, and mechanical strength tests of the mixture containing nickel slag. The test was conducted in the Pavement Laboratory of Directorate General Highway, Ministry of Public Works and Housing.

\section{Analysis and Discussion}

\subsection{Chemical Properties Test results}

Data on the chemical composition of nickel slag waste will provide information on the composition of compounds that will lead to the types of binder and the alternatives of field applications. The results of chemical tests for composition of nickel slag waste are according to Table 1.

Table 1. Chemical Properties Result of Nickel Slag

\begin{tabular}{|c|c|}
\hline Chemical Parameter & Result of Tests \\
\hline $\mathrm{SiO}_{2}$ & $40,39 \%$ \\
\hline $\mathrm{Al}_{2} \mathrm{O}_{3}$ & $6,13 \%$ \\
\hline $\mathrm{Fe}_{2} \mathrm{O}_{3}$ & $8,86 \%$ \\
\hline $\mathrm{K}_{2} \mathrm{O}$ & $0,13 \%$ \\
\hline $\mathrm{CaO}$ & $16,34 \%$ \\
\hline $\mathrm{MgO}$ & $18,66 \%$ \\
\hline $\mathrm{Na}_{2} \mathrm{O}$ & $0,06 \%$ \\
\hline $\mathrm{Cr}_{2} \mathrm{O}_{3}$ & $1,11 \%$ \\
\hline $\mathrm{Mn} 0$ & $0,65 \%$ \\
\hline $\mathrm{LoI}$ & $5,4 \%$ \\
\hline
\end{tabular}


Base on the chemical properties of nickel slag waste in Table 1, there are several main points which can be explained:

- The majority of chemical compound contained in nickel slag are $\mathrm{SiO}_{2}$ or silicate. The compound is the dominant substance in the cement hydration process. Literatures state that silica cannot adhered properly with asphalt. $\mathrm{MgO}$ compound ranks second and relatively high, this compound can cause swelling in the concrete mixture. This makes the utilization of foundation layers with nickel slag more effective than for asphalt or concrete mixtures.

- The $\mathrm{SiO}_{2}, \mathrm{CaO}, \mathrm{Al}_{2} \mathrm{O}_{3}$, and $\mathrm{Fe}_{2} \mathrm{O}_{3}$ elements are the constituent elements of cement, therefore in nickel slag waste there were binding agents.

- LoI value is very low this means that the combustion process occurs perfectly so that the remaining carbon content is very low, which is less than $6 \%$. The presence of carbon particles in road construction material will weaken the bond.

\subsection{TCLP Test results}

TCLP test results data will provide information about the content of hazardous substances present in nickel slag waste. The TCLP nickel slag test results are in accordance with Table 2.

Table 2. TCLP Test Results of Nickel Slag Waste

\begin{tabular}{|c|l|c|c|c|c|c|}
\hline \multirow{2}{*}{ No } & \multirow{2}{*}{ Parameter } & \multirow{2}{*}{ Unit } & \multirow{2}{*}{ Results } & \multicolumn{2}{|c|}{ Requirement } & \multirow{2}{*}{ Methods } \\
\cline { 5 - 6 } & & & TCLP-A & TCLP-B & \\
\hline 1 & Antomony & $\mathrm{Mg} / \mathrm{L}$ & $<0,04$ & 6 & 1 & US EPA \\
\hline 2 & Arsenic & $\mathrm{Mg} / \mathrm{L}$ & $<0,07$ & 3 & 0,5 & US EPA \\
\hline 3 & Barium & $\mathrm{Mg} / \mathrm{L}$ & 0,03 & 210 & 35 & US EPA \\
\hline 4 & Beryllium & $\mathrm{Mg} / \mathrm{L}$ & $<0,03$ & 4 & 0,5 & US EPA \\
\hline 5 & Boron & $\mathrm{Mg} / \mathrm{L}$ & 0,05 & 150 & 25 & US EPA \\
\hline 6 & Cadmium & $\mathrm{Mg} / \mathrm{L}$ & $<0,01$ & 0,9 & 0,15 & US EPA \\
\hline 7 & Chromium & $\mathrm{Mg} / \mathrm{L}$ & $<0,01$ & 15 & 2,5 & US EPA \\
\hline 8 & Copper & $\mathrm{Mg} / \mathrm{L}$ & $<0,01$ & 60 & 10 & US EPA \\
\hline 9 & Lead & $\mathrm{Mg} / \mathrm{L}$ & 0,06 & 3 & 0,5 & US EPA \\
\hline 10 & Mercury & $\mathrm{Mg} / \mathrm{L}$ & $<0,018$ & 0,3 & 0,05 & US EPA \\
\hline 11 & Molybidenum & $\mathrm{Mg} / \mathrm{L}$ & $<0,01$ & 21 & 3,5 & US EPA \\
\hline 12 & Nickel & $\mathrm{Mg} / \mathrm{L}$ & 7,47 & 21 & 3,5 & US EPA \\
\hline 13 & Selecium & $\mathrm{Mg} / \mathrm{L}$ & $<0,13$ & 3 & 0,5 & US EPA \\
\hline 14 & Silver & $\mathrm{Mg} / \mathrm{L}$ & $<0,03$ & 40 & 5 & US EPA \\
\hline 15 & Selenium & $\mathrm{Mg} / \mathrm{L}$ & $<0,13$ & 3 & 0,5 & US EPA \\
\hline 16 & Zink & $\mathrm{Mg} / \mathrm{L}$ & $<0,03$ & 40 & 5 & US EPA \\
\hline
\end{tabular}

Based on the results of TCLP tests of nickel slag waste, the total toxic content is smaller than TCLP-B. This means that nickel slag waste can be used as a substitute of natural aggregates for pavement.

\subsection{Physical Properties Test Results}

To find out whether it can be used as road material, nickel slag waste must be tested for physical properties and compared with the standard for road material. The tests of physical properties are abrasion (\%), specific gravity, absorption (\%), angularity (\%), passes \# 200 sieve $(\%)$, flakiness index, $(\%)$, weathering $(\%)$, clay lumps $(\%)$, and grain analysis $(\%)$. The results of test of the nickel slag physical properties are in accordance with Table 3 . The 
physical appearances of the nickel slag with a sudden cooling on granulation pond system as shown on Figure 2.

Table 3. Physical Properties Laboratory Test results with Granulation Pond System

\begin{tabular}{|c|l|c|c|}
\hline No & Type of Testing & Result Testing & Base Layer Specification \\
\hline 1 & Abration, $\%$ & 50 & Max. 40\% \\
\hline 2 & Specific Gravity & & - \\
\hline & Bulk & 2,81 & - \\
\hline & SSD & 2,83 & - \\
\hline & Apparent & 2,88 & Max. 5\% \\
\hline 3 & Absorption, $\%$ & 0,8 & Min. 90/95 \\
\hline 4 & Angularity, $\%$ & $77 / 77$ & Max. 10\% \\
\hline 5 & Pass \# 200, $\%$ & 2,3 & \\
\hline 6 & Flakiness, $\%$ & 0 & Min.95 \\
\hline 7 & Weathering, $\%$ & 2,26 & \\
\hline 8 & Clay Lumps, $\%$ & 0,018 & \\
\hline 9 & Asphalt Adhesion & Less than 95 & \\
\hline 10 & Grain analysis, $\%$ & & \\
\hline & $-11 / 2 "$ & 100,00 & \\
\hline & $-1 "$ & 99 & \\
\hline & $-3 / 4 "$ & 98 & \\
\hline & $-1 / 2 "$ & 9 & \\
\hline & - 9,52 $(3 / 8$ ") & 74 & \\
\hline & - No. 4 & 24 & \\
\hline & - No. 8 & 6,6 & \\
\hline & - No. 10 & 5,4 & \\
\hline & - No. 16 & 3,8 & \\
\hline & - No. 20 & 3,4 & \\
\hline & - No. 30 & 3,1 & \\
\hline & - No. 40 & 2,9 & \\
\hline & - No. 50 & 2,7 & \\
\hline & - No. 80 & 2,5 & \\
\hline & - No. 100 & 2,3 & \\
\hline & - No. 200 & & \\
\hline & & & \\
\hline
\end{tabular}
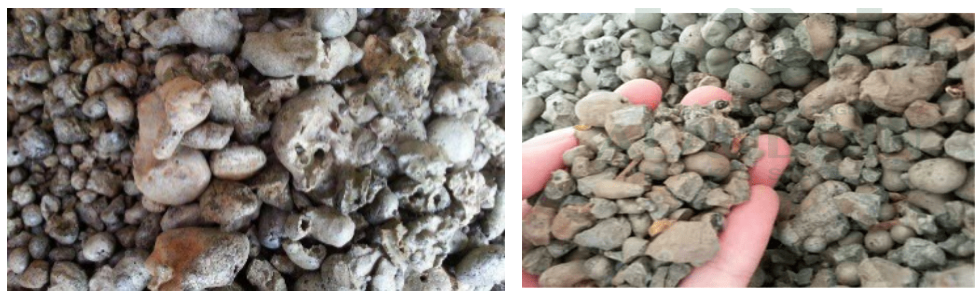

Fig 2. Physical Form of Nickel Slag Waste with Granulation Pond System

Based on laboratory test data for the physical properties of nickel slags with sudden cooling by granulation ponds, there are several important notes to utilize it for road pavement materials, which are:

- High abrasion value: $50 \%$, specification requires not more than $40 \%$ of abrasion value. Abrasion is coarse aggregate properties related to the resistance to loads. Abrasion is an aggregate breakdown process due to mechanical processes such as forces that occur during the road constructions activities (landfills, overlays, compactions), services to traffic loads, and chemical processes, such as the influence of humidity, heat, and 
temperature change throughout the day. A good aggregate is an aggregate with a low abrasion value and vice versa [9]

- Nickel slag angularity is less than 95/90 and round physical shape which causes interlocking between nickel slag is low. This can cause the value of stability or the ability of pavement in accepting the load is low [10].

The low quality of the nickel slag waste is influenced by the carried out waste management process, where the hot nickel slag with a temperature $>1550 \mathrm{C}$ is directly inserted into the granulation pond, to facilitate the process of transportation to the nickel slag dumping.

Based on TCLP test results, chemical properties, and physical properties of nickel slag waste, the potential utilization for nickel slag waste from sudden cooling process is suitable for foundation layer. Due to the low of asphalt adhesion and the content of $\mathrm{MgO}$, nickel slag waste is may be not effective to be use in asphalt or concrete mixtures.

Acceptance criteria for foundation layer are California Bearing Ratio (CBR) values. The base layer requires a minimum CBR value of $90 \%$, a minimum CBR value for sub base layer is $60 \%$, and a minimum CBR value for embankment layer is $10 \%$ [11]. CBR tests for nickel slag with granulation pond system were carried out by soaked and un-soaked conditions. Based on the results of tests conducted, the CBR value of soaked is $34 \%$ and un-soaked CBR is $44 \%$ according to Table 4.

Table 4. Result of CBR Nickel Slag Waste with Pond Granulation System

\begin{tabular}{|c|c|c|c|c|}
\hline \multicolumn{1}{|c|}{ Testing } & Methods & Soak & Unsoaked & Unit \\
\hline Compaction & SNI 1742:2008 & \multicolumn{2}{|c|}{3,10} & $\%$ \\
\hline Optimum Water Content (Wopt) & & \multicolumn{2}{|c|}{1,90} & $\%$ \\
\hline Maximum Dry Density & & 34 & 44 & $\%$ \\
\hline California Bearing Ratio (CBR) & SNI 03-1744-2012 & \multicolumn{2}{|c|}{40} & $\%$ \\
\hline
\end{tabular}

Based on the CBR test results, the nickel slag processed by the sudden cooling in granulation pond method only suitable to be used as an embankment fill. Embankment fill is used to achieve the required final subgrade elevation.

This research seeks to increase the potential for more massive utilization of nickel slag to reduce the accumulation of nickel slag waste overburden. This research examines the alternative waste management system, where nickel slag waste will be tested without going through a process of sudden cooling in pond granulation, in accordance with the results of previous analysis that the sudden cooling system in granulation pond has a negative effect on nickel slag waste for road materials.

Specimens of nickel slag waste without sudden cooling in granulation pond were taken from PT Growth Java Industry Cilegon, West Java. Nickel slag waste were poured into an open area and allowed to stand for several hours until it hardens. Then the process of breaking is done by using a stone crusher. Unlike the sudden cooling system, in this process the size of the nickel slag waste can be adjusted as needed. Documentation of the process and physical form of nickel slag without sudden cooling is shown in Figure 3. The results of test for physical properties of nickel slag with cooling process without granulation pond are shown in Table 4.

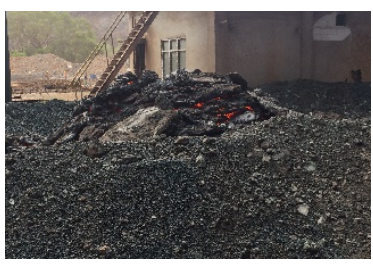

a. Hot Nickel Slag

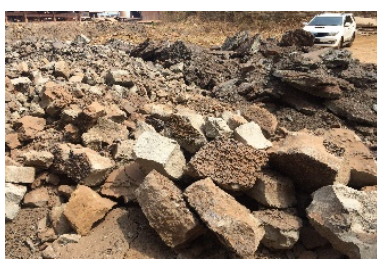

b. Cold Nickel Slag

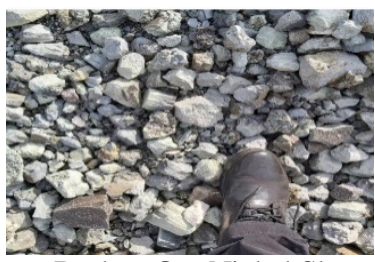

c. Broken Out Nickel Slag 
Fig 3. Physical Form and Process of Nickel Slag Without Sudden Cooling in Granulation Pond

Table 5. Result of Testing Nickle Slag Waste Without Sudden Cooling in Granulation Pond

\begin{tabular}{|c|c|c|c|c|c|}
\hline No & Testing & $\begin{array}{c}\text { Rough } \\
\text { Aggregate }\end{array}$ & $\begin{array}{c}\text { Middle } \\
\text { Aggregate }\end{array}$ & $\begin{array}{c}\text { Fine } \\
\text { Aggregate }\end{array}$ & $\begin{array}{c}\text { Base Layer } \\
\text { Specification }\end{array}$ \\
\hline 1 & Abration, $\%$ & 39,5 & - & - & Max. $40 \%$ \\
\hline \multirow[t]{4}{*}{2} & Specific Gravity & & & & \\
\hline & Bulk & 2,82 & 2,75 & 2,92 & - \\
\hline & SSD & 2,86 & 2,79 & 2,93 & - \\
\hline & Apparent & 2,94 & 2,87 & 2,95 & - \\
\hline 3 & Absorption, \% & 1,40 & 1,54 & 0,40 & Max. 5\% \\
\hline 4 & Angularity, \% & $100 / 100$ & $100 / 100$ & - & Min. 90/95 \\
\hline 5 & Comparison pass \# 200 / \#40 & - & 0,26 & 0,33 & $2 / 4$ \\
\hline 6 & Flakiness, \% & 0 & 0 & - & Max. $10 \%$ \\
\hline 7 & Weathering, \% & 0,1 & 0,2 & 0,9 & Max. 3\% \\
\hline 8 & Clay Lumps, $\%$ & 0 & 0,02 & 1,22 & $\operatorname{Max} 5 \%$ \\
\hline \multirow[t]{18}{*}{9} & Grain analysis, $\%$ & & & & \\
\hline & $-2 "$ & 100 & & & - \\
\hline & $-11 / 2 ”$ & 98 & & & - \\
\hline & $-1 "$ & 57 & & & - \\
\hline & $-3 / 4 "$ & 17 & 100 & & - \\
\hline & $-1 / 2 "$ & - & 62 & & - \\
\hline & $-9,52\left(3 / 8^{\prime \prime}\right)$ & - & 32 & 100 & - \\
\hline & - No. 4 & - & 6 & 98 & - \\
\hline & - No. 8 & - & 2 & 61 & - \\
\hline & - No. 10 & - & 2 & 55 & - \\
\hline & - No. 16 & - & 1 & 40 & - \\
\hline & - No. 20 & - & 1 & 28 & - \\
\hline & - No. 30 & - & 1 & 20 & - \\
\hline & - No. 40 & - & 1 & 16 & - \\
\hline & - No. 50 & - & 1 & 12 & - \\
\hline & - No. 80 & - & 0,8 & 9 & - \\
\hline & - No. 100 & - & 0,7 & 8 & - \\
\hline & - No. 200 & - & 0,3 & 5 & - \\
\hline
\end{tabular}

The results of tests for physical properties of the nickel slag without sudden cooling in granulation pond, shows that there are several noticeable increases in abrasion and angularity properties that fulfil the specifications. Grain size is adjustable as needed. The CBR test for nickel slag waste were carried out by mixing $47 \%$ coarse aggregate, $7 \%$ medium aggregate, and $44 \%$ fine aggregate. The gradation of combined aggregate is shown in Table 6.

Table 6. Gradation Aggregate for Base Layer Pavement with Nickel Slag Waste

\begin{tabular}{|c|c|c|c|c|}
\hline \multirow{2}{*}{ Size Gradation } & \multicolumn{2}{|c|}{ Specification } & \multirow{2}{*}{$\begin{array}{c}\text { Mixed } \\
\text { Gradation }\end{array}$} & \multirow{2}{*}{ Unit } \\
\cline { 2 - 3 } & Min. & Max. & \\
\hline $11 / 2 "(37,5 \mathrm{~mm})$ & 100 & 100 & 100 & $\%$ Pass \\
\hline 1 " $(25,4 \mathrm{~mm})$ & 79 & 85 & 80 & $\%$ Pass \\
\hline $3 / 8 "(9,52 \mathrm{~mm})$ & 44 & 58 & 46 & $\%$ Pass \\
\hline No. $4(4,75 \mathrm{~mm})$ & 29 & 44 & 43 & $\%$ Pass \\
\hline No. $10(2,00 \mathrm{~mm})$ & 17 & 30 & 24 & $\%$ Pass \\
\hline No. $40(0,425 \mathrm{~mm})$ & 7 & 17 & 7 & $\%$ Pass \\
\hline No. $200(0,075 \mathrm{~mm})$ & 2 & 8 & 2 & $\%$ Pass \\
\hline
\end{tabular}


The results of compaction and CBR tests with above composition are in accordance with Table 7.

Table 7. Result of Nickel Slag CBR Test Without Pond Granulation System

\begin{tabular}{|l|c|c|c|c|}
\hline \multicolumn{1}{|c|}{ Testing } & Method & Soaked & Unsoaked & Unit \\
\hline Compaction & SNI 1742:2008 & \multicolumn{3}{|c|}{10,27} \\
\hline Water Content Optimum (Wopt) & & \multicolumn{2}{|c|}{2,61} & $\%$ \\
\hline Dry Density Maximum & & 115 & 167 & $\%$ \\
\hline CBR & SNI 03-1744-2012 & \\
\hline
\end{tabular}

Based on the results of physical properties, compaction, and CBR tests of nickel slag without sudden cooling in pond granulation, the aggregate fulfils the requirements as road base layer. CBR value in soaked condition is greater than the minimum requirement of $90 \%$.

Comparison of physical properties of nickel slag for road material with and without sudden cooling in granulation pond is shown in Table 8 . The graph of the strength of the mixture for the CBR test compared with the specifications for the base layer and embankment is shown in Figure 4.

Table 8. Comparison of Results of Physical Properties Nickel Slag with and Without Pond Granulation

\begin{tabular}{|c|c|c|c|c|}
\hline \multirow[b]{2}{*}{ No } & \multirow[b]{2}{*}{ Descriptions } & \multicolumn{2}{|c|}{ Test Results } & \multirow[b]{2}{*}{ Remarks } \\
\hline & & $\begin{array}{c}\text { With } \\
\text { Granulation Pond }\end{array}$ & $\begin{array}{c}\text { Without } \\
\text { Granulation Pond }\end{array}$ & \\
\hline 1 & Abrasion, \% & $50 \%$ & $39,5 \%$ & Minimum $40 \%$ \\
\hline 2 & Angularity, $\%$ & $77 / 77$ & $100 / 100$ & Minimum 90/95 \\
\hline 3 & CBR (Soaked), $\%$ & $34 \%$ & $115 \%$ & $\begin{array}{l}\text { - Base Layer } \geq \\
90 \% \\
\text { - Sub base layer } \geq \\
60 \% \\
\text { - Embankment } \geq \\
10 \%\end{array}$ \\
\hline 4 & Physical Form & $\begin{array}{l}\text { Round and smooth } \\
\text { surface }\end{array}$ & $\begin{array}{c}\text { Cubical and Rough } \\
\text { surface }\end{array}$ & $\begin{array}{l}\text { Cubical and rough, } \\
\text { very stable and } \\
\text { strong interlocking }\end{array}$ \\
\hline
\end{tabular}




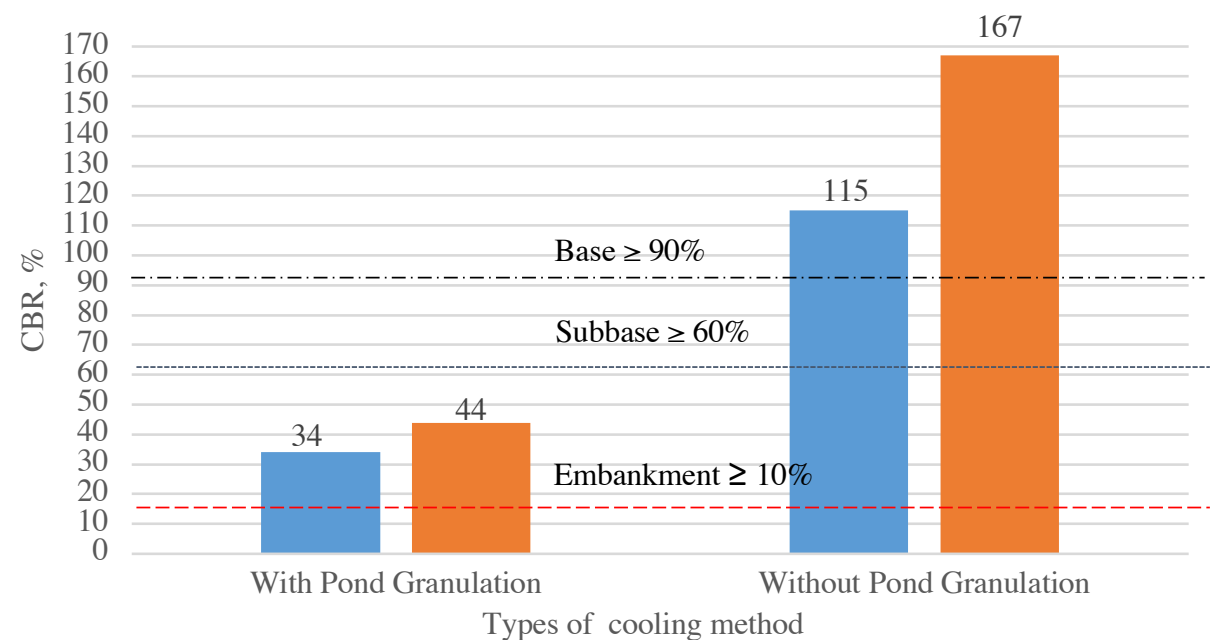

«CBR Soaked $\quad$ CBR Unsoaked

Fig 4. CBR Comparison of Nickel Slags

\section{Conclusions and Recommendations}

\subsection{Conclusions}

Based on the analysis of tests that has been carried out, several conclusions are as follows:

a) Chemical test results shows the majority compound of nickel slag waste is $\mathrm{SiO}_{2}$ or silicate. The constituent elements of cement $\left(\mathrm{SiO}_{2}, \mathrm{CaO}, \mathrm{Al}_{2} \mathrm{O}_{3}\right.$, and $\left.\mathrm{Fe}_{2} \mathrm{O}_{3}\right)$ presents in high concentration.

b) TCLP test results shows the content of hazardous substances in nickel slag are below the TCLP-B references, which means they can be used for road material directly.

c) Sudden cooling in granulation pond gives negative impact to the physical properties of nickel slag, namely high abrasion value, low adhesion to binder (asphalt), low angularity, and causing rounded shape.

d) Nickel slag waste with a sudden cooling in granulation pond system are only suitable for embankment fill because the CBR value only reaches $34 \%$.

e) The physical properties of nickel slag from a system without sudden cooling in granulation pond indicate fulfillment for utilization as road base material. The grain size of nickel slag with this system can be adjusted as needed. The results of the CBR value also showed CBR (soaked) value of $115 \%$, which higher than $90 \%$ as specified.

f) Waste management of nickel slag method without sudden cooling in granulation pond and followed by mechanical crushing process is effectively produces high quality materials for road base.

\subsection{Recommendations}

A full scale trials are important to be carried out on the use of nickel slag as a road base pavement material to determine the field performance and occurred environmental effects. 


\section{References}

[1] A. Harlia. Pemanfaatan Limbah Ampas Nikel PT Antam Pomala untuk Kontruksi Beton. Makasar, UIN Alauddin, Indonesia (2016)

[2] A. Swamy and A. Das. Possible Use of Some Waste Materials in Road Construction. The Master Bulider. Sustainability Road Contruction. Page 44-48, India (2012)

[3] K. Aravin and A. Das. 2004. Industrial Waste in Highway Contruction, Pebbles, 1* issue, Society of Civil Engineers, IIT Kanpur, India (2002)

[4] I. Ahmed, and CW. Lovell. Usage of Waste Materials in Highway Construction: State and Practice Evaluation of the Selected Waste Product. Transportation Research Record. School of Civil Engineering. Indiana Departement of Transportation. India (1991)

[5] W. Mustika, I. Salain, I K. Sudarsana. Penggunaan Terak Nikel Sebagai Agregat dalam Campuran Beton. Jurnal Spektra, Volume 4, No. 2, Page 36-45, Indonesia (2016)

[6] PT Antam, Pengelolaan Slag Ferronikel, Diskusi Potensi Slag Nikel untuk Konstruksi, 21 Maret 2019, Jakarta, Indonesia (2019)

[7] Presiden Republik Indonesia. Peraturan Pemerintah No. 101 tentang pengelolaan limbah bahan berbahaya dan beracun, Jakarta, Indonesia (2014)

[8] Nono. Kajian Penggunaan Lapis Fondasi Agregat yang Distabilisasi Semen. Jurnal Jalan Jembatan. Volume 26, No. 1, Page 1-11, Jakarta, Indonesia (2019)

[9] S. Arifin, M. Kasan, and N. Pradani. Pengaruh Nilai Abrasi Agregat Terhadap Karakteristik Beton Aspal. Jurnal Smartek. Volume 5 No. 1 Februari, Page 1-11, Indonesia (2017)

[10] Misbah, N. Sari. Pengaruh Penggunaan Agregat Kasar Sungai Tuak (Kabupaten Kerinci, Provinsi Jambi) Dalam Campuran Aspal Panas Agregat (Ac-Wc) Dengan Pengujian Marshall. Jurnal Momentum. Volume 20 No. 1 Februari, Page 17-24, Indonesia (2018)

[11] Kementerian Pekerjaan Umum dan Perumahan Rakyat. Spesifikasi Umum Bina Marga. Jakarta Indonesia (2018) 